\title{
Lean Approach for Waste Reduction in Production Line by Integrating DMAIC, VSM, and VALSAT Method (Study Case: Assembling Bracket Manufacturing Automotive Industry)
}

\author{
Muhammad Kholil1, Adizty Suparno², Adizty Suparno33, Rizki Aprilia4 \\ 1,2,4 Department of Industrial Engineering, Universitas Mercu Buana, Jl. Meruya Selatan No. 1, West Jakarta \\ ${ }^{3}$ Department of Industrial and Engineering Management, Universiti Tun Hussein Onn Malaysia, Parit Raja, Johor
}

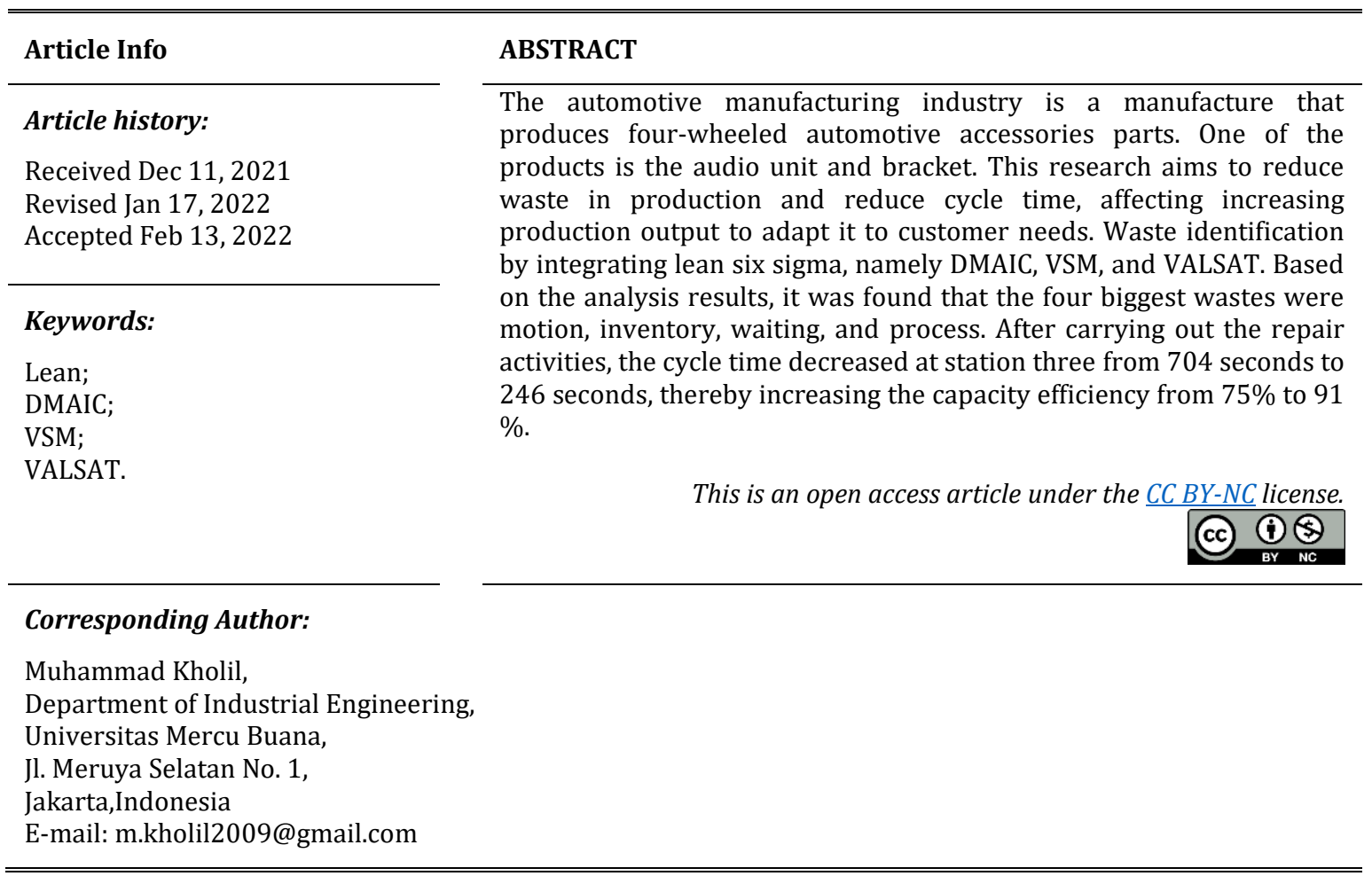

\section{Introduction}

The development of the industrial sector in Indonesia is very fast, especially in the manufacturing sector. Indonesia has occupied the second most prominent position in Southeast Asia after Thailand. An automotive manufacturing industry located in Karawang is a manufacturing company that supplies four-wheeled automotive parts to several Car Maker customers such as Honda and Mitsubishi. The development of the automotive business in Indonesia, increasing every year, has made the industry continue to innovate to meet customer needs by developing a car audio unit assembling supply business. The problem that is being faced by the industry during its development period is that the cycle time is too high and cannot meet the needs of customers.

It is necessary to reduce waste in the audio bracket assembly production line to solve the problem. One method that can be used to optimize a production line is the lean six sigma method. Lean is a continued effort to eliminate waste (waste) and increase the value-added (value-added) of products (goods or services) to provide value to the customer (customer value). The aim is to improve 
the Lean is customer value through the continued increase ratio between the value added to the waste (the value to waste ratio) [1][2].

Six Sigma is a continuous effort (continuous improvement efforts) to decrease the variation of the process, improve capability processes, products (goods or services), which are non-error methods (zero defect) [3][4]. The methods that will be used to optimize audio bracket production are DMAIC (Define, Measure, Analyze, Improve, and Control), VSM (Visual Stream Mapping), and VALSAT (Value Stream Analysis Tools).

\section{Method}

In this study, data collection was carried out by conducting observations in the audio bracket assembly production line at each work station. This research uses qualitative and quantitative data types obtained directly from the company concerned. The analyzes were performed with the approach of the lean manufacturing method DMAIC (Define, Measure, Analyze, Improve, and Control), VSM (Value Stream Mapping), and VALSAT (Value Stream Analysis Tools). Here are some data processing steps:

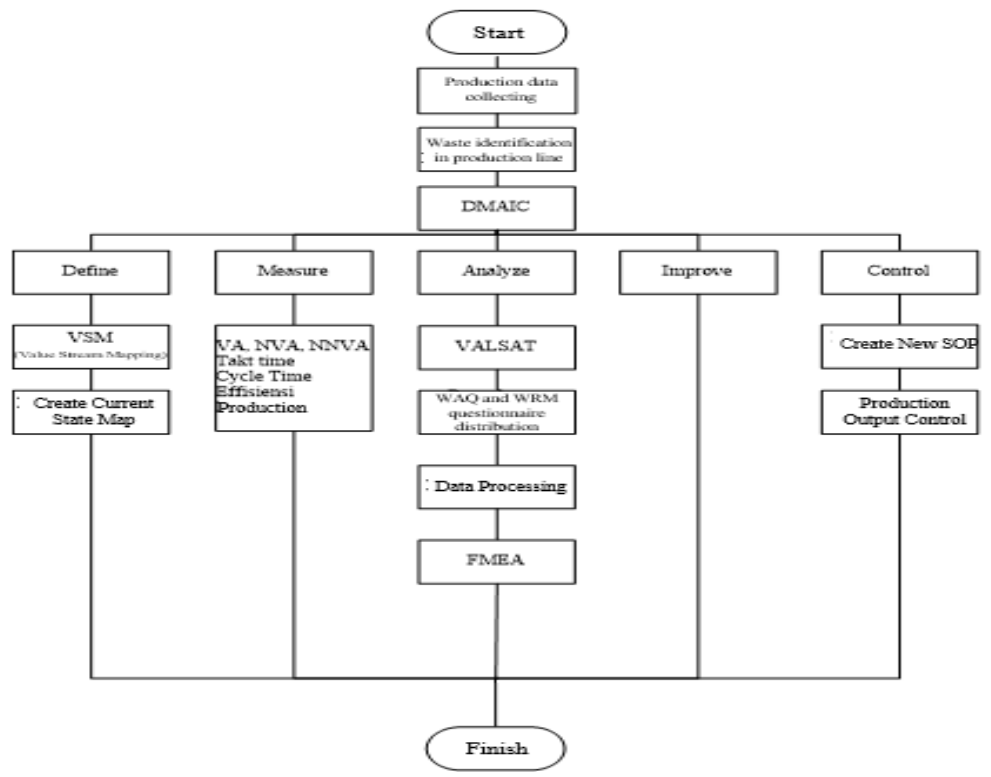

Figure 1. Research flow

\subsection{Lean}

Lean is a continual effort ( continuous improvement Efforts ) to eliminate waste (waste) and to increase the value-added (value-added) of products (goods or services) to deliver results to customers ( customer value ) [2].

\subsection{Waste}

In general, there are Seven plus One Type of Waste contained in the production system [2], namely:

a. Overproduction occurs because producing goods more than customer needs, resulting in an accumulation of the product to require transportation, storage, inspection, and possibly causing defects.

b. Waiting Time (Delay) is caused due to an imbalance on the production line so that delays are seen through people waiting for machines, equipment, and raw materials.

c. Transportation is waste in the form of movement around the production floor. 
d. Over-processing is caused by excessive processing that the customer does not desire. The company makes product specifications beyond the customer's wishes, so it often creates waste in production.

e. Motion is a type of waste caused by movements not required by an operator or mechanic, such as walking or searching for tools or materials.

f. Inventory can be in the form of raw materials, work in process, or finished goods.

g. Defect Product This type of waste can be called scrap caused by consumer dissatisfaction with the product so that the product is returned to the company other than that the process is not good.

h. Defective Design, a design that has unnecessary features or not meets customer needs.

Waste reduction can be applied by simple 5S (Seiri, Seiton, Seiketsu, and Shitsuke). Seiri stands to minimize unnecessary items. Seiton refers to keep the work tool and space tidy. Seiso means to keep the workspace clean. Seiketsu is about maintaining Seiri, Seiton, and Seiketsu continuously. Shitsuke is about a mindset to make discipline become a habit. This method also can improve the quality of the product [3].

\subsection{DMAIC (Define, Measure, Analyze, Improvement and Control)}

a. Define (D) aims to identify the product or process that will be improved and determine what resources are needed in project implementation [4].

b. Measure (M) relates to the measurement that involves in the process.

c. Analyze (A) shows three stages in Six Sigma quality control where things need to be done. Firstly, establish performance targets of quality characteristics (CTQ) to improve the Six Sigma project. Next, identify the sources and root causes of defects or failures. And the last, Converts multiple failures into quality failure costs.

d. Improve (I) the development plan is an important activity in the Six Sigma quality improvement program.

e. Control (C) is the final operational stage in a Six Sigma quality control project. This stage where the results of the control carried out is documented and disseminated. Best practices that are successful in improving the process are standardized and disseminated. Procedures for duration are documented and used as standard work guidelines and ownership or process responsibility, which means a Six Sigma project. It ends at this stage.

\subsection{VSM (Visual Stream Mapping)}

VSM is a method that describes all existing processes in a company [5]. The description of the entire process is depicted with certain symbols on a sheet of paper. The production process in question is from raw materials to products in the hands of consumers. Value Stream Mapping is depicted by symbols representing activities where there are two activities, namely value-added and non-valueadded. A big picture of VSM can help identify the unnecessary process and show the future map's improvement process [6].

\subsection{VALSAT (Value Stream Analysis Tools)}

Value stream analysis tools are tools developed by Hines \& Rich to make it easier to understand the existing value stream mapping analysis and make it easier to make waste repairs. The following is the VALSAT table used for tool selection in the value stream. The value stream analysis column is used to map in detail the value stream, which focuses on the value-adding process. De tailed mapping can then be used to find the cause of the waste that occurs [7]. There are seven kinds of detailed mapping tools that are most commonly used: Process Activity Mapping, Supply Chain Response Matrix, Production Variety Funnel, Quality Filter Mapping, Demand Amplification Mapping, Decision Point Analysis, and Physical Structure.

\subsection{Failure Mode Effects Analysis (FMEA)}

FMEA is the systematics of activities that identify and evaluate potential failure rates in a system, product, or process, especially at the root functions of the product or process on the factors that affect the product or process [8]. FMEA is done to produce RPN values by multiplying the RPN (Risk Priority Number) value by multiplying the rating severity, occurrence, and detection values [9]. FMEA can prioritize the process to be improved and the quality of the production process [10]. 


\section{Result and Discussion}

\subsection{Waste Identification and Improvement}

Here is an overview of the process that created the current state mapping.

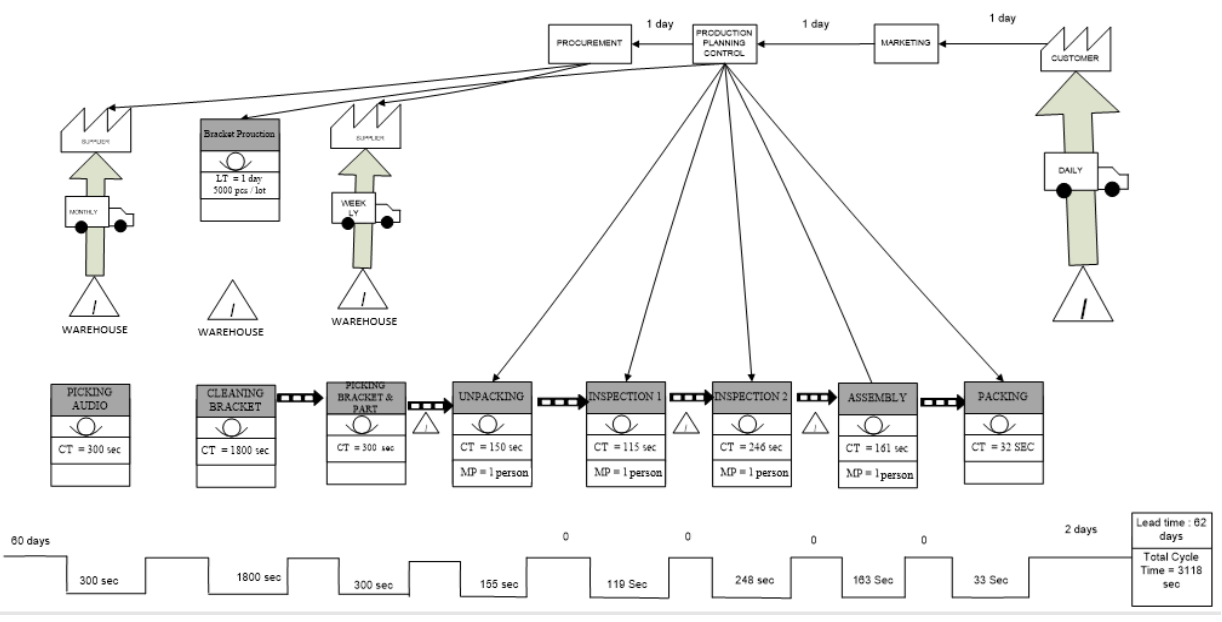

Figure 2. Current Stream Map For Audio Bracket Assembling Process

Based on the analysis by integrating DMAIC, VSM, and VALSAT. The following is a chart of questionnaire data processing results.

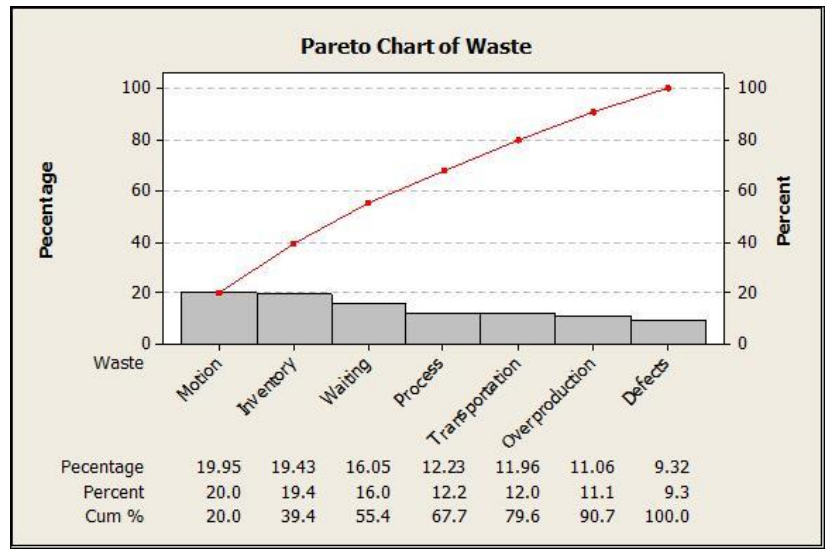

Figure 3. Percentage of Waste Rate

The result of the analysis was continued with the PFMEA to determine the RPN value.

TABLE 2

PFMEA ANALYSIS AND IMPROVEMENT

\begin{tabular}{|c|c|c|c|c|c|c|c|}
\hline No. & Type of Waste & Failure & $\mathrm{S}$ & 0 & $\mathrm{D}$ & Recommendation & RPN \\
\hline 1 & Motion & $\begin{array}{l}\text { Audio stamp processing } \\
\text { failure }\end{array}$ & 4 & 10 & 8 & $\begin{array}{l}\text { Create an audio support jig } \\
\text { for the stamp so that the } \\
\text { audio surface is flat }\end{array}$ & 320 \\
\hline 2 & Motion & $\begin{array}{l}\text { Failure of fitting the audio } \\
\text { unit assembly into the } \\
\text { Checking Fixture that has } \\
\text { been calibrated }\end{array}$ & 4 & 10 & 5 & $\begin{array}{l}\text { Changing the pin model on } \\
\text { the Checking Fixture from } \\
\text { cylindrical to conical type }\end{array}$ & 200 \\
\hline 3 & Motion & $\begin{array}{l}\text { The jig assembly moves } \\
\text { during the assembling } \\
\text { process of the audio unit }\end{array}$ & 2 & 9 & 5 & $\begin{array}{l}\text { Locks the assembling jig so } \\
\text { that it does not move during } \\
\text { the assembling process }\end{array}$ & 90 \\
\hline
\end{tabular}




\begin{tabular}{|c|c|c|c|c|c|c|c|}
\hline No. & Type of Waste & Failure & $\mathrm{S}$ & 0 & $\mathrm{D}$ & Recommendation & RPN \\
\hline 4 & $\begin{array}{l}\text { Waiting \& } \\
\text { Inventory }\end{array}$ & Oily bracket & 6 & 10 & 8 & $\begin{array}{l}\text { Transferring the brackets } \\
\text { manufacturing process to the } \\
\text { subcontractor at a lower } \\
\text { process price compared to in- } \\
\text { house and included in the } \\
\text { delivery of brackets in clean } \\
\text { condition }\end{array}$ & 480 \\
\hline 5 & $\begin{array}{l}\text { Waiting \& } \\
\text { Inventory }\end{array}$ & $\begin{array}{l}\text { Taking the bracket takes a } \\
\text { long time }\end{array}$ & 7 & 10 & 1 & $\begin{array}{l}\text { relay-out and relocation } \\
\text { storage bracket }\end{array}$ & 70 \\
\hline 6 & Waiting & $\begin{array}{l}\text { Operator } 5 \text { waiting time is } \\
\text { too long }\end{array}$ & 1 & 10 & 1 & $\begin{array}{l}\text { Combining } 4 \& 5 \text { station } \\
\text { activities into } 1 \text { operator }\end{array}$ & 10 \\
\hline 7 & Process & $\begin{array}{l}\text { Process cycle time is too } \\
\text { long }\end{array}$ & 7 & 10 & 4 & $\begin{array}{l}\text { Perform workload balancing } \\
\text { for each work station }\end{array}$ & 280 \\
\hline
\end{tabular}

The next step was carried out from the improvements to the audio bracket assembly production line. Big Future Mapping was made, which was used as a reference in determining and controlling procedures.

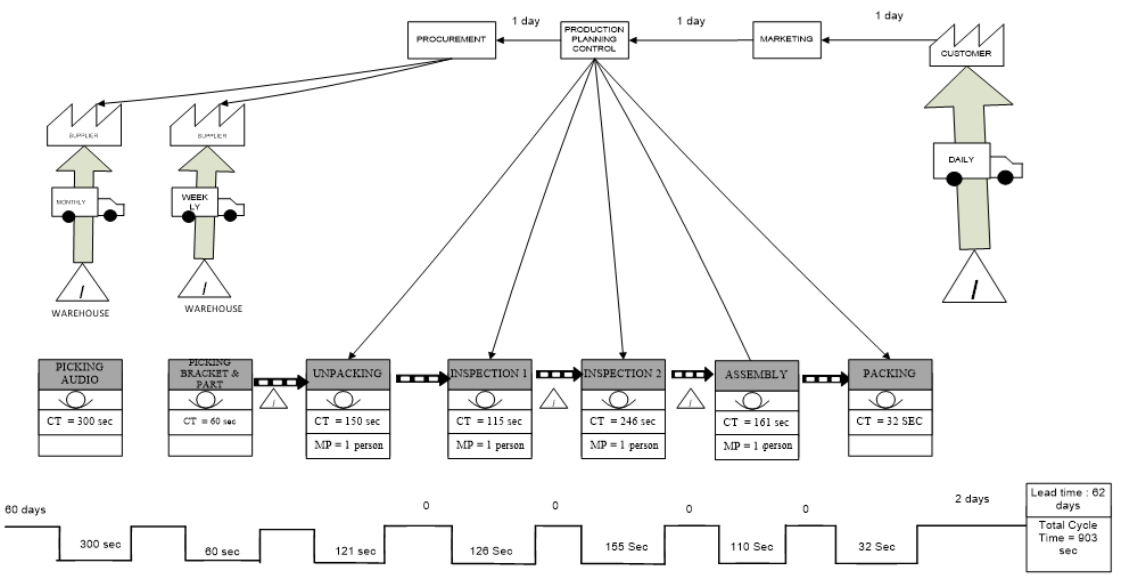

Figure 3. Future stream map for audio bracket assembling process

\subsection{VA and NVA}

Reducing waste in the audio bracket assembly line is as follows: a comparison of Value Added Time and Non-Value Added Time.

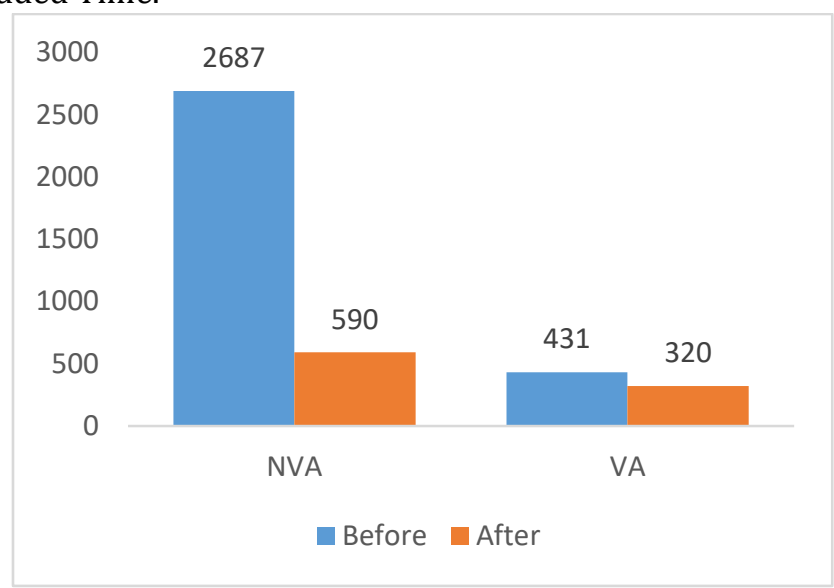

Figure 4 Comparison Graph of VA and NVA 
On stage define, with the goal of waste promoted to major on-line production assembling integrate it with Value Stream Mapping method in big picture / current state mapping. At this stage, potential activities can be identified by identifying Value Added (VA) and Non-Value Added (NVA).

\subsection{Reduction of Cycle Time}

Minimizing waste on the audio bracket assembling production line has a significant impact in reducing cycle times. The following is a comparison of the cycle time before and after the repair.

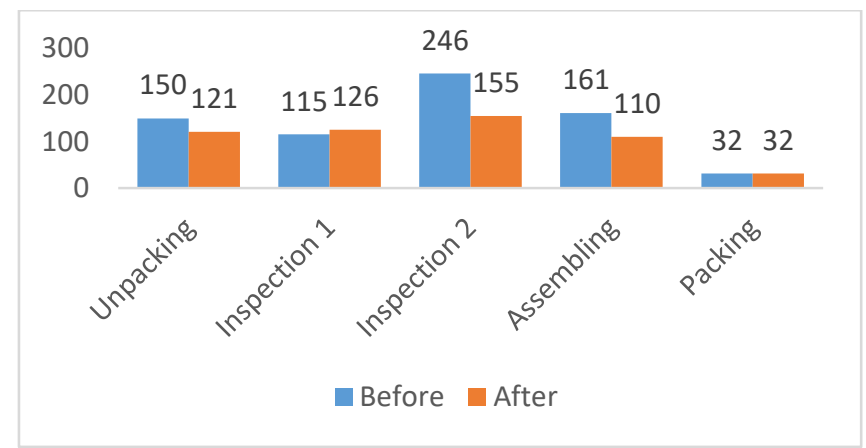

Figure 5. Cycle Time Comparison Graph

\subsection{Increased Production Capacity Efficiency}

The following is a comparison of the efficiency of the audio bracket assembling production capacity. The following is a graph of the comparison of the production capacity of the audio bracket assembling.

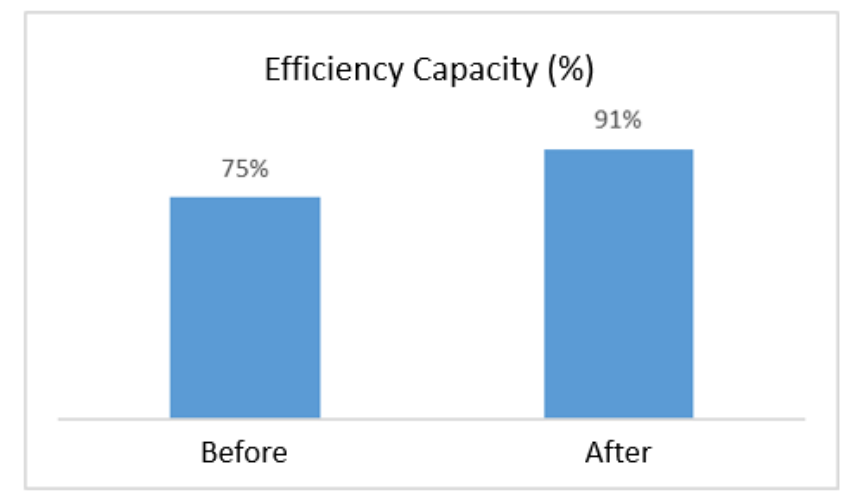

Figure 6. Comparison Chart of Production Capacity Efficiency

\section{Conclusion}

Based on the results of integrating lean six sigma with DMAIC, VSM, and VALSAT tools, it can be seen that the causes of waste that occur in the audio bracket assembling production line, namely motion, inventory, waiting, and process. The first cause of waste is motion caused by a failure in the audio stamp labeling process, failure of fitting the audio assembly unit into the calibrated checking fixture, and the jig assembly that moves during the audio unit assembly process. The second waste of Waiting \& Inventory is caused by oily brackets, which take time to clean, and long bracket removal time due to the farther position of the brackets than the other parts. The third waste is waiting, where operator 5 waits too long for input from the fourth operator. The fourth waste is a process that makes cycle time too high.

The total cycle time on the current activity is 704 seconds, with the bottleneck (longest cycle time) at station 3 (inspection 2), 246 seconds. After the repair stage, there was a decrease in the total cycle time to 543 seconds with the longest cycle time, namely at station 3 (inspection 2), which also 
decreased to 155 seconds. The reduced cycle time resulted in a capacity efficiency that increased from $75 \%$ to $91 \%$.

\section{References}

[1] V. Gasperz, Production Inventory Management. For Supply Chain Proffesional. Strategi menuju World Class Manufacturing. Bogor: Vinchristo Publication, 2012.

[2] Z. L. Dima, "Penggunaan Konsep Lean untuk Meningkatkan Efisiensi Pelayanan Instalasi Farmasi Rawat Jalan di Rumah Sakit Anna Medika Bekasi," J. Adm. Rumah Sakit Indones., vol. 2, no. 1, 2018.

[3] V. Gasperz and A. Fontana, Lean Six Sigma for Manufacturing and Service Industries. Waste Elimination and Continuous Cost Reduction. Bogor: Vinchristo Publication, 2011.

[4] A. Töpfer and A. Töpfer, Six sigma. Springer Berlin Heidelberg, 2007.

[5] H. Purba, D. Santoso, and J. Haekal, "5S APPLICATION TRAINING ( SEIRI , SEITON , SEIS Ō, SEIKETSU , AND SHITSUKE ) TO IMPROVE THE QUALITY OF WORK ENVIRONMENT IN THE SERVICE INDUSTRY,” no. 2014, pp. 2014-2016, 2016.

[6] A. Syukron and M. Kholil, Six Sigma for Business Improvement. Graha Ilmu, 2013.

[7] J. Shook and M. Rother, Learning to See Value Stream Mapping to Create Value and Elimite Muda. United State of America: he Lean Enteprise, Inc, 2003.

[8] M. Kholil, J. Haekal, and S. Hasan, "Lean Manufacturing Design to Reduce Waste in Gear Production Process Using VSM and Kaizen Method Approaches ( Case Study: Gear Primary Driven K56 Product )," vol. 7, no. November 2019, pp. 1-9, 2020.

[9] D. Dimancescu, P. Hines, and N. Rich, The Lean Enterprise Designing and Managing Strategic Processes for Customer-Winning Performance. New York: AMACOM, 1997.

[10] D. Caesaron and S. Y. P. S. Simatupang, "Implementasi Pendekatan DMAIC untuk Perbaikan Proses Produksi Pipa PVC (Studi Kasus PT. Rusli Vinilon),” J. Metris, 16 91-96, vol. 16, pp. 91-96, 2015.

[11] R. Hidayat, I. P. Tama, and R. Y. Efranto, "Penerapan Lean Manufacturing Dengan Metode VSM Dan FMEA Untuk Mengurangi Waste Pada Produk Plywood (Studi Kasus Dept. Produksi PT Kutai Timber Indonesia)," J. Univ. Brawijaya, vol. 5, no. 2, pp. 1032-1043, 2014.

[12] A. A. Hidayat, M. Kholil, Hendri, and Suhaeri, "The Implementation of FTA (Fault Tree Analysis) and FMEA (Failure Mode and Effect Analysis) Methods to Improve the Quality of Jumbo Roll Products," IOP Conf. Ser. Mater. Sci. Eng., vol. 453, no. 1, 2018. 